\title{
Bringing healthcare to the UK's abused domestic workers
}

As we wrap up this year's winter appeal, Richard Hurley reports on some of Doctors of the World's work in London. The charity is well versed in bringing care to the most vulnerable people in developing and developed countries. You've raised more than £25 000 so far, and there's still time to donate

\section{Richard Hurley features and debates editor, The BMJ}

In an anonymous office building near Holborn underground station, some of London's most vulnerable residents meet every Sunday-for many, their only day off work. The group Justice for Domestic Workers (www.j4dw.com) campaigns for the rights of the roughly 16000 foreign maids, nannies, and housekeepers in the United Kingdom. It has more than 1000 members.

Predominantly women aged $25-65$, from countries as disparate as the Philippines, Nigeria, and India, they work in wealthy households, including for foreign royalty, diplomats, and British military officers, Marissa Begonia, a housekeeper and the group's coordinator, told The BMJ. Some are pregnant or have young children.

The isolation of domestic work makes physical and sexual abuse common. But foreign workers can be wary about coming forward and having to prove ill treatment because they risk deportation.

UK law changed in 2012 to tie working visas to a single employer: now if employees quit they could breach immigration rules, and they risk becoming undocumented. Unscrupulous employers take advantage of this.

"Do we need to be raped and beaten and starved to get protection?" asked Begonia. "The system legalises the abuse." The group provides its members with clothes, English classes, travel grants, employment advice, childcare, access to legal advice and representation - and now healthcare. Doctors of the World has recently started sending volunteers once a month to the group's meeting.

\section{Everyone's entitled to free primary care}

Everyone, including undocumented people, is entitled to free NHS primary care, as the Royal College of General Practitioners has made clear, ${ }^{1}$ but many practice receptionists and managers apply unnecessarily onerous restrictions to registration. Domestic workers often lack proof of address and have had their passports confiscated, for example, but they shouldn't need to show these to register with a GP.

"A person's immigration status shouldn't be a block to accessing healthcare," said David Haigh, a nurse specialist who volunteers for Doctors of the World as a clinical support worker and who writes to practices to help workers register formally with GPs. "Receptionists say no. Managers say no. We get passed from pillar to post."

In addition to Doctors of the World's permanent clinic in Bethnal Green, the charity has started to run pop-up clinics targeting marginalised people who lack access to primary healthcare. As well as the one in Holborn for domestic workers, they attend groups in London for Latin American women, French speaking migrants from north Africa, and African men who have sex with men, for example.

"Last week we had 10-15 people signed up to see a doctor [at the Holborn pop-up clinic] but nobody turned up because there'd been a lot of arrests," he said.

"We need more volunteer doctors, but my biggest fear is the government's proposals for 'health tourists' to pay for GP services. It will make things really hard. It's very short sighted."

Jenny Akhurst, a GP based in Peckham volunteering at the clinic for domestic workers, described some of the health problems she'd seen. "There are a lot of unmonitored chronic health conditions-for example, someone with high blood pressure who's never seen a doctor in the UK. Or with diabetes who's never had it rechecked - and they're sharing their friend's insulin and taking drugs sporadically, so their diabetes is poorly controlled. I've seen complications from that." However, it's often acute problems that trigger the need to see a doctor.

\section{History of violence}

"Obviously we see mental health issues as well," she said. "We try to ask everybody about history of violence. It's much more common than you think." Domestic workers may have been 
abused by people smugglers, employment agents, employers, and their associates - and even their own families.

One worker, Mary, a 34 year old Filipino, told The BMJ how she ran away from her employer in London in 2013 because of long hours without proper pay and no days off for years. "When undocumented you may not have legal rights but you still have human rights." "I' $m$ registered with a GP-but I haven't been yet. I'm scared that they're going to ask lots of things."

A nanny, 56 year old Eliza, came to the UK in 2011 after escaping Saudi Arabia, where she'd been made to sleep on the nursery floor of a palatial house for 20 years, she said. But when she fell ill in London her new employer told her to go back to the Philippines.

"I was bleeding. My stomach was swelling. I could not access the GP because I was new here. It was cancer: a malignant tumour in the ovary," she told The BMJ, tears running down her face. "It's now gone. I'm free. I have a new employer; he understands me."

She found Justice for Domestic Workers after hospital doctors contacted them. Of the pop-up clinic she said, "I tell my friends, if you don't have a GP you can access one here."

Doctors of the World has more than 350 projects to bring healthcare to vulnerable people in more than 80 countries and its independence depends on it being funded solely by private donations, which means it can work solely in the interests of vulnerable people like Eliza and Mary.

\section{See related articles:}

Feinmann J. Support the volunteer doctors helping the world's refugees. BMJ 2015;351:h6515.

Feinmann J. Restoring Africa's health systems after Ebola. BMJ 2015;351:h6841.

Hurley R. Vandals force volunteer doctors to close clinic in Calais's refugee camp. BMJ 2016;352:1182.

http://blogs.bmj.com/bmj/2015/12/29/sarah-pickworth-helping-refugeesin-greece/

http://blogs.bmj.com/bmj/2015/12/17/mohammed-bakir-a-refugee-campon-the-fringes-of-society/

http://blogs.bmj.com/bmj/2015/12/04/bmj-christmas-appeal-how-doctorsof-the-world-helps-refugees-across-europe/

1 Royal College of General Practitioners. Asylum seekers and vulnerable migrants: failed asylum seekers/vulnerable migrants and access to primary care. RCGP position statement. 2013. www.rcgp.org.uk/policy/rcgp-policy-areas/asylum-seekers-and-vulnerable-migrants. aspx.

Cite this as: BMJ 2016:352:1502

(c) BMJ Publishing Group Ltd 2016 


\section{How much have you donated to Doctors of the World?}

In two months readers have raised a total of $£ 25195$ ( $€ 33000, \$ 36000)$. You made 80 donations through the website, sent more than 70 cheques, and made more than 50 donations by text message. Donations have come from widespread destinations, including Toronto and Malta. Doctors of the World thanks all The BMSs readers for their support

It's still not too late to donate

- $£ 80$ could provide 10 psychological consultations for survivors of war

- $£ 135$ could provide an emergency backpack containing drugs and consumables used by mobile doctors to treat refugees in Greece and the Balkans

- $£ 180$ could provide 25 hygiene kits for refugees living in poor sanitary conditions throughout Europe

- Donate online: www.doctorsoftheworld.org.uk/BMJ

- Donate $£ 10$ by text message: text DOCTOR to 70660 (UK mobiles only)

- Donate by phone: +44 (0)20 35357955 